\title{
Kinetic and Thermodynamic Characterization of two Polygalacturonases Isolated from the Digestive Juice of the Snail Limicolaria flammea
}

\author{
Bernard Téhi Sea ${ }^{1}$, Armand Kouassi Kanga ${ }^{1}$, Djary Michel Koffi ${ }^{\star *}$ \\ and Lucien Patrice Kouamé ${ }^{2}$ \\ ${ }^{1}$ Laboratory of Biotechnologies, Agriculture and Valorization of the Biological Resources, 22 BP 582 \\ Abidjan 22, Côte d'Ivoire. \\ ${ }^{2}$ Laboratory of Biochemistry and Food Technology, Nangui Abrogoua University, 02 BP 801, Abidjan \\ 02, Côte d'Ivoire. \\ Authors' contributions \\ This work was carried out in collaboration among all authors. All authors read and approved the final \\ manuscript. \\ Article Information \\ DOI: $10.9734 / A R R B / 2021 / v 36 i 1030436$ \\ Editor(s): \\ (1) Prof. Md. Aminur Rahman, Jashore University of Science and Technology, Bangladesh. \\ Reviewers: \\ (1) Fabiana Queiroz, Universidade Federal de Lavras, Brazil. \\ (2) Elia Elizabeth Pérez-Reyes, Universidad Nacional de Colombia, Colombia. \\ Complete Peer review History: https://www.sdiarticle4.com/review-history/72804
}

Original Research Article

Received 01 July 2021

Accepted 07 September 2021 Published 18 October 2021

\begin{abstract}
Polygalacturonases are extensively used in food industries for pectic substances degradation. In this paper, we investigate on thermal stability parameters of two Polygalacturonases previously isolated from digestive juice of the snail Limicolaria flammea for several industrial applications such as fruit juice clarification. Thermal inactivation was carried out in the temperature range of $55^{\circ} \mathrm{C}$ to $80^{\circ} \mathrm{C}$ from 15 to $120 \mathrm{~min}$. All results were statistically analysed. The results shown that thermal inactivation of studied acid phosphatases follows first order kinetics. At their optimum temperatures, these enzymes showed high half-lives ranging from 462.06 to $630.10 \mathrm{~min}$ and $\mathrm{D}$ values from 1535.00 to 2093.64 min suggesting that these two enzymes had a large thermal stability. The high values of $\Delta \mathrm{G}^{\#}(93.96$ to $94.97 \mathrm{~kJ} / \mathrm{mol})$ reveal a better resistance to denaturation. The relatively high activation energies (from 120.35 to $129.13 \mathrm{~kJ} / \mathrm{mol}$ ) and average enthalpy values (from 117.67 to $126.44 \mathrm{~kJ} . \mathrm{mol}-1$ ) could corroborate the good stability of these biocatalyst. All these results suggest that Polygalacturonases from digestive juice of the snail Limicolaria flammea may be profitably exploited in future food industrial applications.
\end{abstract}


Keywords: Polygacturonase; Snail Limicolaria flammea; thermal stability.

\section{INTRODUCTION}

Pectinases are a versatile group of enzymes that degrade or modify pectin substances, which are complex polysaccharides present as the major components in the middle lamella and primary cell walls in plants $[1,2]$. Known pectinases are classified into three groups, pectinesterases, depolymerizing pectinases, and protopectinases [3], which represent around $25 \%$ of the commercial sales of food enzymes. These enzymes (pectinases) are widespread in nature and are produced by bacteria, filamentous fungi, plants, and animals $[4,5]$. Pectinases have many applications in the industry, especially in the extraction of fruit juices. These enzymes reduce viscosity by degrading pectin in the middle layer, which facilitates subsequent processes like juice filtration [1]. The incorporation of pectinolytic enzymes also preserves the nutritional value, original color, and flavor [6].

Among these pectinases, polygalacturonases have more important industrial applications due to their stability to various physicochemical and thermodynamic parameters

Polygalacturonase (E.C. 3.2.1.15) is a hydrolytic pectinase with affinity for galacturonic acid glycosidic linkages [8]. Numerous studies have already been carried out on polygalacturonase production and its applications in the industrial and other bioprocess fields [9-13]. So, it is well known that temperature is a key variable in bioprocesses using enzymes [14]. According to Silva et al. [15] thermodynamic studies determine the thermal stability and economic viability of enzymes in food and non-food systems. Indeed, the enzyme that remains active in wide temperature ranges for longer time are usually considered as practicable and economical from industrial point of view [16]. Thus, high stability is generally considered an economic advantage because it reduces the enzyme loss and consequently the costs of the process [17]. Following Souza et al. [17], thermodynamic and kinetic studies can provide valuable information about the thermostability of enzymes at a given operating temperature. Mozhaev [18] and Illanes [19] argue that enzyme stability represents a critical point in most bioprocesses.

Most of the polygalacturonases used in bioprocesses are of microbial origin [4,12]. To our knowledge, very few studies have been carried out to polygalacturonases animal sources. As regards polygalacturonases PG1 and PG2 previously isolated from the digestive juice of the snail Limicolaria flammea by Kanga et al. [20], no study has been devoted to their thermal stability parameters. Therefore, objective of the current study was to determined thermal stability parameters (Speed consistency, activation energy, half-life time, decimal reduction time, temperature of destruction, temperature coefficient, enthalpy, entropy et Gibbs free energy) of the two polygalacturonases purified from digestive juice of the snail Limicolaria flammea [20] for several industrial applications such as fruit juice clarification.

\section{MATERIALS AND METHODS}

\subsection{Enzymatic Source and Crude Extract Preparation}

Snail Limicolaria flammea were collected locally in Côte d'Ivoire at the National Floristic Center of the University Felix Houphouet-Boigny $\left(5^{\circ} 21^{\prime} \mathrm{N}\right.$ and $3^{\circ} 54^{\prime} \mathrm{W}$ ). After isolation of the digestive tract, the digestive fluid was collected in a jar placed in ice, filtered through cotton wool, and then centrifuged at $10,000 \times \mathrm{g}$ for $30 \mathrm{~min}$ at $4^{\circ} \mathrm{C}$. The supernatant constituted the crude extract.

\subsection{Enzyme Activity Assay}

The polygalacturonase activity was determining by using the 3.5-dinitrosalicylic acid (DNS) method [21] with D-(+)-galacturonic acid as the standards. All reactions contained $200 \mu \mathrm{L}$ of $0.5 \%$ of polygalacturonic acid (PGA), $200 \mu \mathrm{L}$ of $100 \mathrm{mM}$ sodium acetate buffer $(\mathrm{pH} 5.6)$ and 50 $\mu \mathrm{L}$ of enzyme solution. The reaction mixture was incubated at $37^{\circ} \mathrm{C}$ for $30 \mathrm{~min}$. After incubation, $300 \mu \mathrm{L}$ DNS was added to terminate the reaction, followed by 5 -min incubation in boiling water bath. The absorption at $540 \mathrm{~nm}$ was measured at room temperature. All experiments were performed in triplicate. One unit $(U)$ of polygalacturonase was defined as the amount of enzyme that released reducing sugars equivalent to $1 \mu \mathrm{mol}$ of $\mathrm{D}-(+)$-galacturonic acid per min under the standard conditions. The specific activity was expressed as unit of activity per $\mathrm{mg}$ of protein.

\subsection{Proteins Estimation}

Protein concentrations and elution profiles from chromatographic columns were determined by 
the Folin method [22]. Bovine serum albumin (BSA) was used as the standard protein.

\subsection{Thermal Inactivation}

The thermal inactivation of each purified polygalacturonases was determined at various constant temperatures from 50 to $70{ }^{\circ} \mathrm{C}$. Enzymes in sodium acetate buffer $(\mathrm{pH} 5.6)$ were exposed to each temperature for a period of 15 to 120 minutes. Then, aliquots were withdrawn at intervals (15 minutes) and immediately cooled at $4^{\circ} \mathrm{C}$ for 20 minutes. Residual activities, determined at $37^{\circ} \mathrm{C}$ under the standard enzyme assay conditions, were expressed as percentage of activity of zero-time control of untreated enzymes.

\subsection{Residual Activity}

$$
\text { Residual activity (\%) }=(\text { At } / A 0) \times 100
$$

where $A t$ and $A 0$ are the activities of the treated and untreated enzyme solution, respectively.

\subsection{Kinetic Data Analysis}

\subsubsection{Denaturation constants of the enzyme fraction $k$}

Thermal inactivation of each phosphatase can be described by a first-order kinetic model [23]. The integral effect of an inactivation process at constant temperature, where the inactivation rate constant is independent of time, is given in Equation /(1) as follows:

$$
\ln (A t / A O)=-k t \text { (first-order } k \text { inetics })
$$

where $A t$ is the residual enzyme activity at time $t$ (minutes), $A 0$ is the initial enzyme activity, $k$ (minute-1) is the inactivation rate constant at a given condition. $k$ values were obtained from the regression line of In $(A t / A o)$ versus time as slope.

\subsubsection{Determination of half-life of the enzyme solution $\mathrm{t} 1 / 2$}

The $t 1 / 2$ was obtained from the following equation:

$$
t 1 / 2=\ln 2 / k
$$

\subsubsection{Calculation of activation Energy Ea}

The Ea was obtained from the Arrhenius equation:

$$
k=A \cdot e^{-(E a R / T)}
$$

where $k$ is the first-order rate constant of thermal inactivation of the enzyme activity, obtained through the slopes of the plots described above, $\mathrm{R}=8.314 \mathrm{~J} \mathrm{~K}-1 \mathrm{~mol}-1$ is the universal gas constant and $T$ represents the absolute temperature $(\mathrm{K})$.

\subsubsection{Calculation of temperature coefficient (Q10)}

The temperature coefficient (Q10) is the rate of change of the enzymatic catalytic reactions for each $10^{\circ} \mathrm{C}$ rise in temperature. It is the ratio of the percentage of activity $\mathrm{X} 10$ of the reaction at temperature $\mathrm{T}+10{ }^{\circ} \mathrm{C}$ to the percentage of activity $\mathrm{X}$ at temperature $\mathrm{T}^{\circ} \mathrm{C}$ using the following formula:

$$
Q 10=X 10 / X
$$

With:

$$
\begin{aligned}
& \mathrm{X} 10=\% \text { activity at } \mathrm{T}+10^{\circ} \mathrm{C} \\
& \mathrm{X}=\% \text { activity at } \mathrm{T}{ }^{\circ} \mathrm{C}
\end{aligned}
$$

\subsubsection{Calculation of $D$ values of the enzyme fractions}

$D$-value is defined as the time needed, at a constant temperature, to reduce the initial enzyme activity $(A 0)$ by $90 \%$ (or decimal reduction time or time required to preincubate the enzyme at a given temperature to maintain $10 \%$ residual activity). For first-order reactions, the $D$ value is directly related to the rate constant $k$ (Eq. 2) $[24,25]$ :

$$
D=\ln (10) / k=2.303 / k
$$

\subsubsection{Calculation of $z$ values of the enzyme fractions}

The $z$ value $\left({ }^{\circ} \mathrm{C}\right)$ is the temperature increase needed to induce a 10 -fold reduction in $D$ value [25]. This $z$ value follows the Eq. (7):

$$
\log (D 1 / D 2)=(T 2-T 1) / z
$$


where $T 1$ and $T 2$ are the lower and higher temperatures in ${ }^{\circ} \mathrm{C}$ or $\mathrm{K}$. Then, $D 1$ and $D 2$ are $D$ values at the lower and higher temperatures in minute, respectively.

The $z$ values were determined from the linear regression of $\log (D)$ vs temperature $(T)$.

\subsubsection{Thermodynamic parameters}

The enthalpy of reaction $(\Delta H \#)$, which is the amount of energy required to bring the enzyme to the activated state for the subsequent denaturation at a given temperature, Gibbs free energy $(\triangle G \#)$ and the entropy $(\triangle S \#)$ were calculated through the following equations [26,27].

$$
\begin{aligned}
\Delta H \# & =E a-R T \\
\Delta G \# & =-R T \times \ln (k \times h / K b \times T)
\end{aligned}
$$

where

$\Delta H \#=$ Change in enthalpy;

$E a=$ activation energy of inactivation;

$R=$ universal gas constant;

$T=$ absolute temperature $(\mathrm{K})$.

$$
\Delta S \#=(\Delta H \#-\Delta G \#) / T
$$

where

$\Delta G \#$ = free energy change of inactivation;

$h=$ Plank's constant $(6,62607 \times 10-34$ $\mathrm{m} 2 . \mathrm{kg} / \mathrm{s}$ );

$K b=$ Bolztman constant $(1,3807 \times 10-23$ $\mathrm{J} / \mathrm{K})$.

$\Delta S \#=$ Change in entropy.

\subsection{Statistical Analysis}

All tests for the different analyses were performed in triplicate and the data obtained were expressed as the arithmetic mean with the corresponding statistical standard deviation. The one factor analysis of variance (ANOVA) was performed on all the results obtained in order to determine the existence of statistically significant differences between the values of the calculated means. Statistically significant differences were highlighted by Duncan's test at $95 \%$ confidence level. This statistical analysis was performed using Statistica 7.1 software.

\section{RESULTS AND DISCUSSION}

In this study, the effect of heat treatment over a range of temperature from 50 to $70^{\circ} \mathrm{C}$ on both polygalacturonases $P G 1$ and $P G 2$ was evaluated by determining the residual percentage activity (Table 1).

The activity of both polygalacturonases was decreases with increasing heating time (5$120 \mathrm{~min})$ and temperature $\left(50-70^{\circ} \mathrm{C}\right)$. Indeed, it is observed that between 50 and $70^{\circ} \mathrm{C}$ thermal denaturation of PG1 and PG2 occurred after 15 min incubation $(97.63 \%$ to $73.20 \%$ and $98.12 \%$ to $81.55 \%$ respectively). Heat treatment at $50^{\circ} \mathrm{C}$ for 120 min resulted in partial inactivation of polygalacturonases PG1 and PG2 (activity of $82.53 \%$ and $87.37 \%$ respectively). Partial inactivation for PG1 (activity: 53.85\%) and PG2 (activity: $49.18 \%$ ) was also observed at $60^{\circ} \mathrm{C}$. However, a strong inactivation of the activity of both enzymes was observed at $70^{\circ} \mathrm{C}$ during the 120 min incubation time (activity of $7.64 \%$ for $P G 1$ and $20.60 \%$ for PG2).

The graphical representations of $\ln A t / A o$ as a function of the pre-incubation time of polygalacturonases at temperatures between 50 and $70^{\circ} \mathrm{C}$ gave affine lines translating a first order thermal inactivation kinetics (Fig. 1).

The inactivation rate constant $(k)$ value and halflife (t1/2) of polygalacturonases PG1 and PG2 from digestive juice snail Limicolaria flammea are presented in Table 2.

The rate constant values increased with temperature from $\left(0.0015\right.$ to $0.0207 \mathrm{~min}^{-1}$ for PG1 et 0.0011 to $0.0146 \mathrm{~min}^{-1}$ for PG2) at 50 $70^{\circ} \mathrm{C}$, respectively. While the half-life (t1/2) decreases with increasing temperature and presents values between 462.00 and $33.48 \mathrm{~min}$ for PG1 and between 630.00 and $47.47 \mathrm{~min}$ for $P G 2$. The $K$ values obtained in this study are lower than those reported in the studies by Adedeji et Ezekiel [28] with the purified polygalacturonases PUo- PG, PCPOF- PG, PUp$P G$ and PCPPF- PG and those of Faiza et al. [29] with the free exo-polygalacturonase. Polygalacturonases PG1 and PG2 are thus more thermostable than these reported biocatalysts. According to Marangoni [30], a lower rate constant means that the enzyme is more thermostable. 
Table 1. Effect of the treatment temperature and time on the inactivation of PG1 and PG2 polygalacturonases of digestive juice snail Limicolaria flammea

\begin{tabular}{|c|c|c|c|c|c|c|c|c|c|c|}
\hline \multirow{3}{*}{$\begin{array}{l}\text { Time } \\
\text { (min) }\end{array}$} & \multicolumn{10}{|c|}{ Residual activity $(\%)$ at each temperature $\left({ }^{\circ} \mathrm{C}\right)$ of heat treatment } \\
\hline & \multicolumn{5}{|c|}{ PG1 } & \multicolumn{5}{|c|}{ PG2 } \\
\hline & 50 & 55 & 60 & 65 & 70 & 50 & 55 & 60 & 65 & 70 \\
\hline 0 & $100 \pm 0^{\mathrm{a}}$ & $100 \pm 0^{\mathrm{a}}$ & $100 \pm 0^{\mathrm{a}}$ & $100 \pm 0^{\mathrm{a}}$ & $100 \pm 0^{\mathrm{a}}$ & $100 \pm 0^{\mathrm{a}}$ & $100 \pm 0^{\mathrm{a}}$ & $100 \pm 0^{\mathrm{a}}$ & $100 \pm 0^{\mathrm{a}}$ & $100 \pm 0^{\mathrm{a}}$ \\
\hline 15 & $97.63 \pm 0.58^{b}$ & $94.65 \pm 0.01^{b}$ & $91.48 \pm 0.01^{b}$ & $81.79 \pm 0.04^{b}$ & $73.20 \pm 0.02^{b}$ & $98.12 \pm 0.01^{b}$ & $97.04 \pm 0.02^{b}$ & $91.30 \pm 0.01^{b}$ & $84.24 \pm 0.03^{b}$ & $81.55 \pm 0^{b}$ \\
\hline 30 & $95.89 \pm 0.17^{c}$ & $90.03 \pm 0.03^{c}$ & $84.96 \pm 0.01^{c}$ & $70.33 \pm 0.03^{c}$ & $54.06 \pm 0.01^{c}$ & $96,95 \pm 0.01^{c}$ & $95.31 \pm 0.02^{c}$ & $84.20 \pm 0.02^{c}$ & $70.87 \pm 0^{c}$ & $65.91 \pm 0.02^{c}$ \\
\hline 45 & $93.43 \pm 0.03^{d}$ & $85.13 \pm 0.02^{d}$ & $78.58 \pm 0.02^{d}$ & $57.64 \pm 0.05^{d}$ & $41.90 \pm 0.01^{d}$ & $95.60 \pm 0.03^{d}$ & $92.97 \pm 0.04^{d}$ & $76.26 \pm 0.02^{d}$ & $60.62 \pm 0^{d}$ & $54.55 \pm 0.01^{d}$ \\
\hline 60 & $91.48 \pm 0.08^{e}$ & $81.38 \pm 0.01^{e}$ & $72.40 \pm 0.03^{e}$ & $48.43 \pm 0.02^{e}$ & $29.43 \pm 0.02^{e}$ & $94.08 \pm 0.01^{\mathrm{e}}$ & $90.66 \pm 0.02^{e}$ & $71.32 \pm 0.01^{\mathrm{e}}$ & $54.01 \pm 0.02^{e}$ & $44.89 \pm 0.01^{\mathrm{e}}$ \\
\hline 75 & $89.40 \pm 0.03^{f}$ & $77.58 \pm 0.03^{f}$ & $66.17 \pm 0.02^{f}$ & $40.90 \pm 0.01^{f}$ & $21.85 \pm 0.02^{f}$ & $92.13 \pm 0.02^{f}$ & $87.89 \pm 0.04^{f}$ & $64.47 \pm 0.01^{f}$ & $45.16 \pm 0.01^{f}$ & $36.79 \pm 0^{f}$ \\
\hline 90 & $87.02 \pm 0.03 \mathrm{~g}$ & $73.48 \pm 0.06 \mathrm{~g}$ & $62.65 \pm 0.01^{g}$ & $33.49 \pm 0.04 \mathrm{~g}$ & $16.12 \pm 0 \mathrm{~g}$ & $90,99 \pm 0.02^{g}$ & $86.61 \pm 0.01 \mathrm{~g}$ & $59.35 \pm 0.04 \mathrm{~g}$ & $39.53 \pm 0.04 \mathrm{~g}$ & $30.36 \pm 0.02^{g}$ \\
\hline 105 & $85.07 \pm 0.01^{\mathrm{h}}$ & $69.05 \pm 0.02^{h}$ & $58.04 \pm 0.01^{h}$ & $27.84 \pm 0.02^{h}$ & $11.28 \pm 0.02^{h}$ & $89,40 \pm 0,05^{h}$ & $83.44 \pm 0.01^{h}$ & $55.72 \pm 0.05^{h}$ & $33.12 \pm 0.03^{h}$ & $24.71 \pm 0.04^{h}$ \\
\hline 120 & $82.53 \pm 0.01^{i}$ & $66.69 \pm 0.01^{i}$ & $53.85 \pm 0.07^{i}$ & $21.98 \pm 0.01^{i}$ & $7.64 \pm 0^{i}$ & $87,37 \pm 0,02^{i}$ & $82.28 \pm 0^{i}$ & $49.18 \pm 0.01^{i}$ & $27.78 \pm 0.01^{i}$ & $20.60 \pm 0.01^{i}$ \\
\hline
\end{tabular}

The averages assigned to the same lowercase letters in a column are not statistically different with a threshold $\alpha=0.05$ 
The half-life values (t1/2) obtained in our study are lower than those reported by Faiza et al. [29] with exo-polygalacturonase immobilized by covalent binding on a sodium alginate matrix using glutaraldehyde as cross-linking agent, and exo-polygalacturonase immobilized by adsorption on a sodium alginate matrix but higher than those of Rapidase C80, Pectinase CCM, Pectinex 3XL and Grindamyl 3PAa [31].

The values of the temperature coefficients (Q10) increase with increasing temperature for PG1, while they decrease with increasing temperature for PG2. Thus between $50-60^{\circ} \mathrm{C}$ and $60-70^{\circ} \mathrm{C}$, the values of Q10 are respectively 3.4667 and 3.9808 for PG1 and 5.2727 and 2.5172. These Q10 values are higher than Q10 values in general during enzymatic reactions (1-2). This implies that the hydrolysis reaction is controlled by factors other than temperature [32].

To establish the link between treatment time and enzyme activity, the D-values were calculated.
The decimal reduction time (D value) was calculated according to equation 5 . As shown in table IV, D-values decreased by increased at temperature, indicating a faster inactivation of polygalacturonases at higher temperatures. These values vary respectively from 1535 to 111 min and from 2093.64 to 157.74 min for PG1 and PG2.

The effect of temperature on D-values is shown in Fig. 2, and from this representation, the Zvalue was calculated and found to be $17.60^{\circ} \mathrm{C}$ et 16.45 for $P G 1$ and $P G 2$ respectly at $50-70^{\circ} \mathrm{C}$ (Table 3 ). These relatively high values imply a lower heat sensitivity of the polygalacturonases PG1 and PG2 and could therefore be used in long term industrial applications (60-120 min) subjected to heat treatments at temperatures between 50 and $70{ }^{\circ} \mathrm{C}$. According to Barrett et al [33], when the $Z$ value is very low, the enzyme is very sensitive to heat.

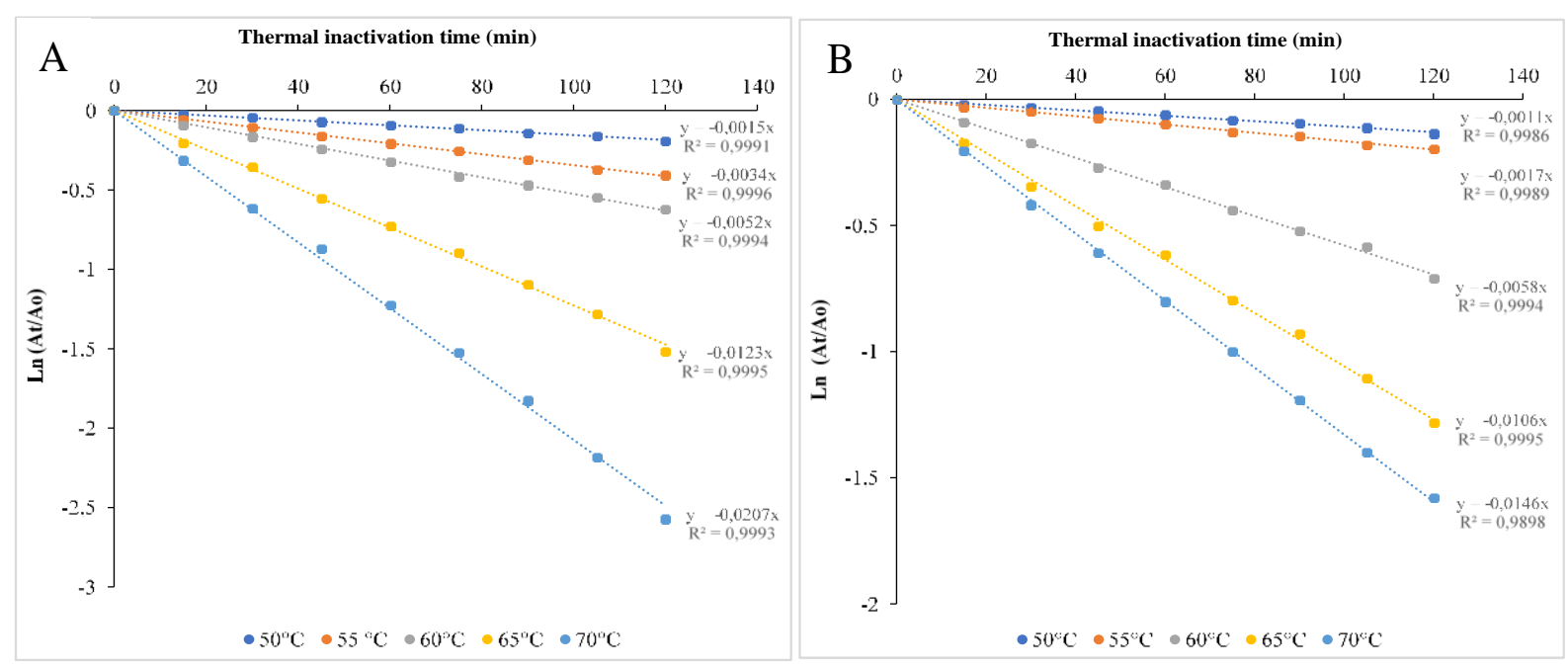

Fig. 1. Thermal inactivation curves of PG1 and PG2 polygalacturonases of digestive juice snail Limicolaria flammea at temperature range $50-70^{\circ} \mathrm{C}$ A: PG1. B: PG2

$A O$ : the initial enzymatic activity, At : the activity at each holding time

Table 2. K-values and $t_{1 / 2}$ for thermal inactivation of PG1 and PG2 polygalacturonases of digestive juice snail Limicolaria flammea at temperature range $\left(50-70^{\circ} \mathrm{C}\right)$

\begin{tabular}{lllll}
\hline Temperatures $\left({ }^{\circ} \mathbf{C}\right)$ & \multicolumn{3}{c}{ PG1 } & \multicolumn{1}{c}{ PG2 } \\
\hline & K-Values $\left(\mathbf{m i n}^{-1}\right)$ & $\mathbf{t}_{1 / 2}(\mathbf{m i n})$ & \multicolumn{1}{c}{ K-Values $\left(\mathbf{m i n}^{-1}\right)$} & $\mathbf{t}_{1 / 2}(\mathbf{m i n})$ \\
\hline $\mathbf{5 0}$ & $0.0015 \pm 0.00^{\mathrm{a}}$ & $462.00 \pm 0.20^{\mathrm{e}}$ & $0.0011 \pm 0.00^{\mathrm{a}}$ & $630.00 \pm 0.20^{\mathrm{e}}$ \\
$\mathbf{5 5}$ & $0.0034 \pm 0.00^{\mathrm{ab}}$ & $203.82 \pm 0.02^{\mathrm{d}}$ & $0.0017 \pm 0.00^{\mathrm{a}}$ & $407.65 \pm 0.01^{\mathrm{d}}$ \\
$\mathbf{6 0}$ & $0.0052 \pm 0.00^{\mathrm{b}}$ & $133.27 \pm 0.20^{\mathrm{c}}$ & $0.0058 \pm 0.00^{\mathrm{b}}$ & $119.48 \pm 0.01^{\mathrm{c}}$ \\
$\mathbf{6 5}$ & $0.0123 \pm 0.00^{\mathrm{c}}$ & $56.34 \pm 0.02^{\mathrm{b}}$ & $0.0106 \pm 0.00^{\mathrm{c}}$ & $65.38 \pm 0.02^{\mathrm{b}}$ \\
$\mathbf{7 0}$ & $0.0207 \pm 0.00^{\mathrm{d}}$ & $33.48 \pm 0.01^{\mathrm{a}}$ & $0.0146 \pm 0.001^{\mathrm{d}}$ & $47.47 \pm 0.00^{\mathrm{a}}$ \\
\hline
\end{tabular}

The averages assigned to the same lowercase letters in a column are not statistically different with a threshold $\alpha$ $=0.05 ; t 1 / 2$ is the half-life constant of polygalacturonases 
In order to determine the thermodynamic parameters for thermal stability, the energy of activation (Ea) for thermal denaturation was determined by applying the Arrhenius plot. Graphical representations of Ink as a function of the inverse of temperature in degrees Kelvin of polygalacturonases PG1 and PG2 also yielded affine lines with negative slopes (Fig. 3). The slopes of these plots (slope $=-E a / R$ ) allowed us to determine the activation energies during thermal inactivation of our polygalacturonases.
The values of activation energy $(\mathrm{Ea})$ recorded in Table 4 are 120.35 and 129.13 KJ.mol-1 for PG1 and PG2 respectively. These high activation energy values indicate that polygalacturonases $P G 1$ and PG2 are highly resistant to high temperatures [34,35]. These activation energy values are higher than those reported by Rodrigo et al. [36] with the free and immobilized pectinase extracted from Aspergillus aculeatus (85.1 and $101.6 \mathrm{~kJ} . \mathrm{mol}-1)$, also higher than that of the polygalacturonase peh 28 [37].

Table 3. Values of the temperature coefficients (Q10) during the thermal inactivation $\left(50-70{ }^{\circ} \mathrm{C}\right)$ of PG1 and PG2 polygalacturonases of digestive juice snail Limicolaria flammea

\begin{tabular}{lll}
\hline & \multicolumn{2}{c}{ Temperature coefficients (Q10) } \\
\hline Temperature interval $\left({ }^{\circ} \mathbf{C}\right)$ & PG1 & PG2 \\
\hline $\mathbf{5 0 - 6 0}$ & $3.4667 \pm 0.02^{\mathrm{a}}$ & $5.2727 \pm 0.01^{\mathrm{b}}$ \\
$\mathbf{6 0 - 7 0}$ & $3.9808 \pm 0.01^{\mathrm{b}}$ & $2.5172 \pm 0.01^{\mathrm{a}}$ \\
\hline
\end{tabular}

The averages assigned to the same lowercase letters in a column are not statistically different with a threshold $\alpha$ $=0.05$

Table 4. D-, Z-, and Ea-values for thermal inactivation of PG1 and PG2 polygalacturonases of digestive juice snail Limicolaria flammea at temperature range $\left(50-70^{\circ} \mathrm{C}\right)$

\begin{tabular}{|c|c|c|}
\hline Kinetic parameters & PG1 & PG2 \\
\hline \multicolumn{3}{|l|}{ D-Values (min) } \\
\hline $\mathrm{D}_{50}$ & $1535 \pm 2.64^{e}$ & $2093.64 \pm 0.86^{j}$ \\
\hline D55 & $677 \pm 1.00^{\mathrm{d}}$ & $1354.71 \pm 4.97^{i}$ \\
\hline$D_{60}$ & $443 \pm 0.17^{c}$ & $397.07 \pm 0.02^{\mathrm{h}}$ \\
\hline$D_{65}$ & $187 \pm 0.46^{b}$ & $217.26 \pm 0.23^{g}$ \\
\hline$D_{70}$ & $111 \pm 0.86^{a}$ & $157.74 \pm 0.65^{\dagger}$ \\
\hline Z-Values $\left({ }^{\circ} \mathrm{C}\right)$ & $17.60 \pm 0.02$ & $16.45 \pm 0.02$ \\
\hline $\mathrm{Ea}\left(\mathrm{KJ} \cdot \mathrm{mol}^{-1}\right)$ & $120.35 \pm 0.03$ & $129.13 \pm 0.04$ \\
\hline
\end{tabular}

The averaged affected of the same tiny letters in a column are not statistically different with a threshold $\alpha=0.05$.

$D$-, Z- and Ea were respectively the decimal reduction time, the constant thermal resistance, and the activation energy of polygalacturonases

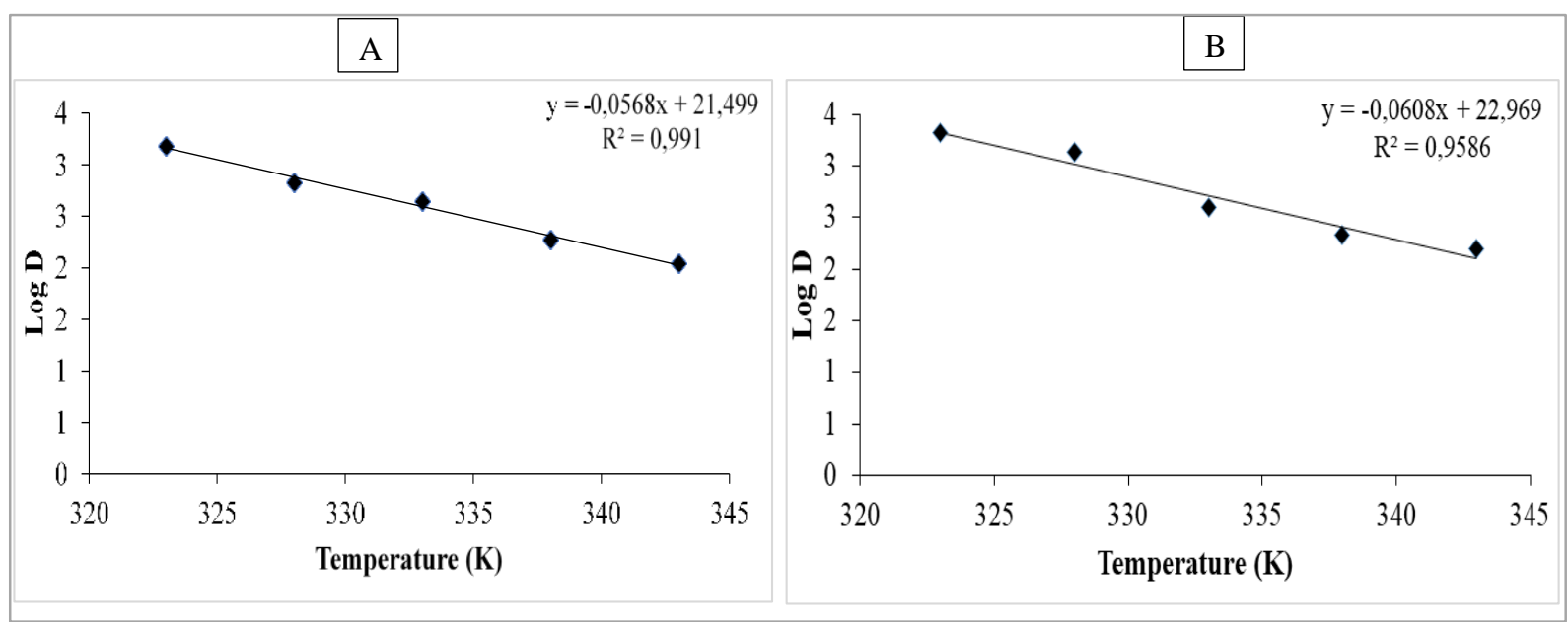

Fig. 2. Effect temperature on D-values for inactivation of PG1 and PG2 polygalacturonases of digestive juice snail Limicolaria flammea

A: PG1; B: PG2 


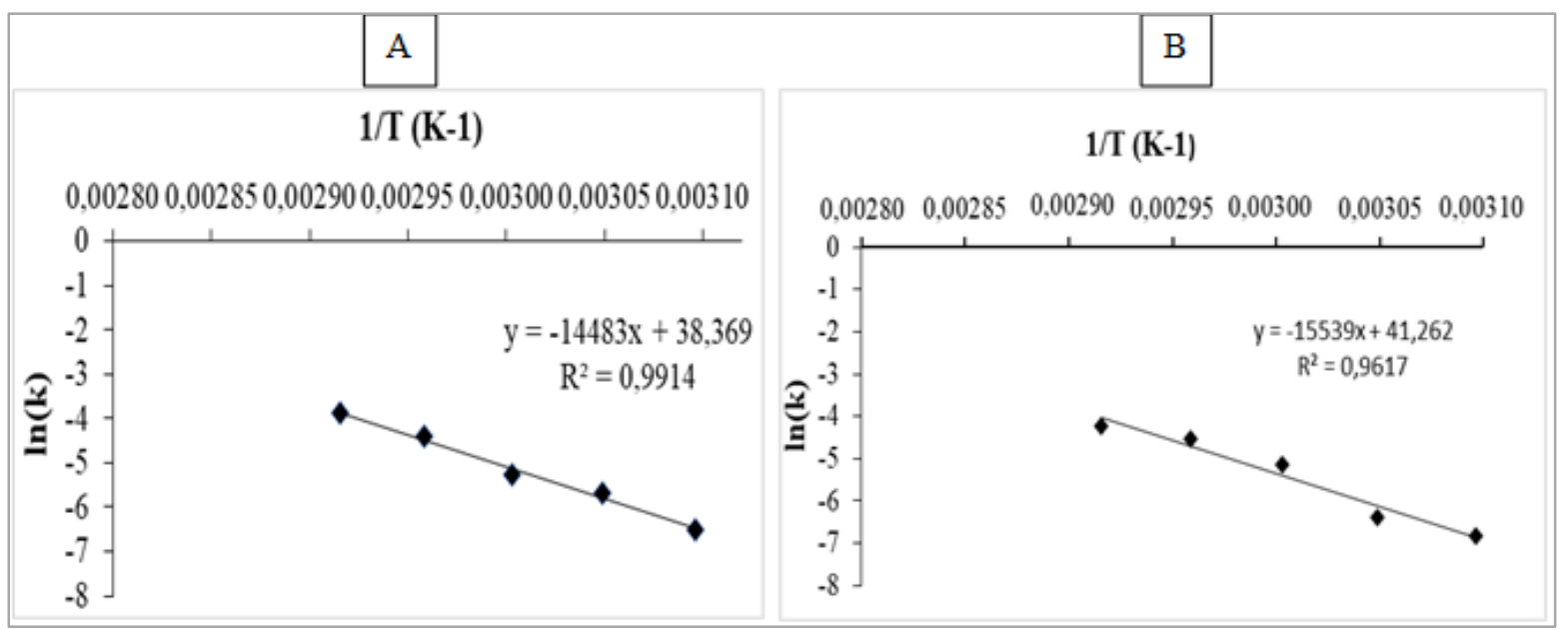

Fig. 3. Effect of the temperature on the constant of the speed (K) during the inactivation of PG1 and PG2 polygalacturonases of digestive juice snail Limicolaria flammea

A: PG1; B: PG2

Table 5. Thermodynamic parameters of PG1 and PG2 polygalacturonases of digestive juice snail Limicolaria flammea under heat treatment between 50 at $70^{\circ} \mathrm{C}$

\begin{tabular}{|c|c|c|c|c|c|c|}
\hline \multirow{3}{*}{$\begin{array}{l}\text { Temperature } \\
\left({ }^{\circ} \mathrm{C}\right)\end{array}$} & \multicolumn{6}{|c|}{ Thermodynamic parameters } \\
\hline & \multicolumn{2}{|c|}{$\Delta \mathrm{H}^{\#}(\mathrm{~kJ} / \mathrm{mol})$} & \multicolumn{2}{|c|}{$\Delta S^{\#}\left(\mathrm{~J} \mathrm{~mol}^{-1} \mathrm{~K}^{-1}\right)$} & \multicolumn{2}{|c|}{$\Delta \mathrm{G}^{\#}(\mathrm{~kJ} / \mathrm{mol})$} \\
\hline & PG1 & PG2 & PG1 & PG2 & PG1 & PG2 \\
\hline 50 & $117.67 \pm 0.010^{\mathrm{e}}$ & $126.44 \pm 0^{\mathrm{e}}$ & $73.40 \pm 0.043^{e}$ & $97.44 \pm 0^{\mathrm{e}}$ & $93.96 \pm 0.016^{e}$ & $94.97 \pm 0^{\mathrm{e}}$ \\
\hline 55 & $117.63 \pm 0.017^{d}$ & $126.40 \pm 0.020^{d}$ & $73.27 \pm 0.010^{d}$ & $97.31 \pm 0.017^{d}$ & $93.59 \pm 0.017^{d}$ & $94.48 \pm 0.023^{d}$ \\
\hline 60 & $117.59 \pm 0^{c}$ & $126.36 \pm 0.010^{c}$ & $73.14 \pm 0.010^{c}$ & $97.18 \pm 0.010^{c}$ & $93.23 \pm 0.003^{c}$ & $93.99 \pm 0.007^{c}$ \\
\hline 65 & $117.54 \pm 0.010^{\mathrm{b}}$ & $126.32 \pm 0.010^{b}$ & $73.02 \pm 0.020^{b}$ & $97.06 \pm 0.036^{b}$ & $92.86 \pm 0.015^{b}$ & $93.51 \pm 0.008^{b}$ \\
\hline 70 & $117.50 \pm 0.026^{a}$ & $126.28 \pm 0.020^{a}$ & $72.89 \pm 0.026^{a}$ & $96.94 \pm 0.010^{a}$ & $92.49 \pm 0.038^{a}$ & $93.03 \pm 0.023^{a}$ \\
\hline Mean & $117.59 \pm 0.003^{c}$ & $126.36 \pm 0.006^{c}$ & $73.14 \pm 0.017^{c}$ & $97.19 \pm 0.002^{c}$ & $93.23 \pm 0.008^{c}$ & $93.99 \pm 0.006^{c}$ \\
\hline
\end{tabular}

$\Delta H \#, \Delta S \#$ and $\Delta G \#$ were respectively variations in enthalpy, entropy and Gibbs free energy 
The thermodynamic values of the variation of enthalpy $(\Delta \mathrm{H} \#)$, entropy $(\Delta S \#)$ and Gibbs' free energy $(\Delta G \#)$ of the polygalacturonases PG1 and PG2 of the digestive juice of the snail Limicolaria flammea calculated at different temperatures are shown in Table 5. The values of enthalpy $(\Delta \mathrm{H} \#)$, entropy $(\Delta S \#)$ and Gibbs free energy $(\Delta G \#)$ during the inactivation of our enzymes are positive. At temperatures between 50 and $70^{\circ} \mathrm{C}$, the mean values of $\Delta \mathrm{H \# ,} \Delta \mathrm{S} \#$ and $\Delta \mathrm{G} \#$ were $117.59 \mathrm{~kJ} . \mathrm{mol}-1,73.14 \mathrm{~J}$ mol-1K-1 and $93.23 \mathrm{~kJ} . \mathrm{mol}-1$ for PG1 and $126.36 \mathrm{~kJ} . \mathrm{mol}-1$, $97.19 \mathrm{~J} \mathrm{~mol}-1 \mathrm{~K}-1$ and $93.99 \mathrm{~kJ} . \mathrm{mol}-1$ for PG2, respectively.

The high enthalpy values of PG1 and PG2 suggest that a large amount of energy is required for the denaturation of our biocatalysts because the breakdown of covalent bonds including interactions is associated with increased enthalpy. This positive value from $\Delta \mathrm{H} \#$ states that the catalytic reaction is endothermic [38]. The positive values found for $\Delta \mathrm{S \#}$ indicate that there is no significant aggregation process for $P G 1$ and PG2, the reaction proceeds with less speed and is characterized by poor regularity [39]. In addition, these high entropy values probably reflect an increased disorder of the active site or structure of our biocatalysts [40]. The variation of $\Delta S$ with increasing temperature could be due to a change in the conformation of the enzyme structure [41]. The values of $\Delta G \#$ were positive, indicating that the processes were endergonic and not spontaneous. The high values of $\Delta G^{*}$ reveal a better resistance to denaturation. However, when the temperature increased from 50 to $70^{\circ} \mathrm{C}$; there was a reduction

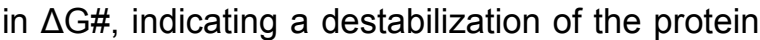
at this temperature [36].

\section{CONCLUSION}

The study of thermodynamic parameters for the inactivation of polygalacturonases PG1 and PG2 in the temperature range of $50^{\circ} \mathrm{C}$ to $70^{\circ} \mathrm{C}$ has shown that our biocatalysts are stable at high temperatures. The D-, Z-, $k$ values of half life, $Q_{10}$ indicate that polygalacturonases PG1 and PG2 are heat stable. The free energy (Ea) and enthalpy $(\Delta \mathrm{H} \#)$ values indicate that a large amount of energy is required to initiate denaturation of these biocatalysts. These interesting results suggest that polygalacturonases $P G 1$ and $P G 2$ can be used in the industrial field for the hydrolysis of polygalacturonic acid, especially for juice clarification.

\section{COMPETING INTERESTS}

Authors have declared that no competing interests exist.

\section{REFERENCES}

1. Trindade LV, Desagiacomo C, Polizeli MDLTD, Damasio ARDL, Lima AMF, Gomes E, Bonilla-Rodriguez GO. Biochemical characterization, thermal stability, and partial sequence of a novel exo-polygalacturonase from the thermophilic fungus Rhizomucor pusillus A13. 36 obtained by submerged cultivation. BioMed Research International. 2016;2016:110.

2. Rehman HU, Aman A, Nawaz MA, Karim A, Ghani M, Baloch AH, Qader SAU. Immobilization of pectin depolymerising polygalacturonase using different polymers. International Journal of Biological Macromolecules. 2016;82:127133

3. Uenojo M, Pastore GM. Pectinases: aplicaoes industriaise perspectivas, Química Nova. 2007;30(2):388-394.

4. Pedrolli DB, Monteiro AC, Gomes E, Carmona EC. Pectin and pectinases: production, characterization and industrial application of microbial pectinolytic enzymes, The Open Biotechnology Journal. 2009;3:9-18.

5. Sharma N, Rathore M, Sharma $M$. Microbial pectinase: Sources, characterization and applications. Rev Environ Sci Biotechnol. 2013;12:45-60.

6. Tapre AR, Jain RK. Pectinases: Enzymes for fruit processing industry, International Food Research Journal. 2014;21(2):447453.

7. Anuradha K, Padma PN, Venkateshwar S, Reddy G. Mango juice clarification with polygalacturonase produced by Aspergillus awamori MTCC 9166 - Optimization of conditions. Int. Food Res. J. 2016;23(1): 147-151.

8. Heerd D, Yegin S, Tari C, FernandezLahore M. Pectinase enzyme complex production by Aspergillus spp. in solidstate fermentation: A comparative study. Food Bioprod Process. 2012;90: 102-110.

9. Dey TB, Adak S, Bhattacharya P, Banerjee R. Purification of polygalacturonase from Aspergillus awamori Nakazawa MTCC 6652 and its application in apple juice 
clarification. LWT - Food Sci. Technol. 2014;59:591-595.

10. Anand G, Yadav S, Yadav D. Purification and characterization of polygalacturonase from Aspergillus fumigatus MTCC 2584 and elucidating its application in retting of Crotalaria juncea Fiber. 3 Biotech. 2016;6:201-207.

11. Fitch-Vargas PR, Aguilar-Palazuelos E, Vega-García MO, Zazueta-Morales JJ, Calderón-Castro A, Montoya-Rodríguez A, Camacho-Hernández IL. Effect of a corn starch coating obtained by the combination of extrusion process and casting technique on the postharvest quality of tomato. Revista Mexicana de Ingeniería Química. 2019;18:789801.

12. Munir M, Abdullah R, Haq IU, Kaleem A, lqtedar $M$, Ashraf S. Purification, characterization, kinetics and thermodynamic analysis of polygalacturonase from Aspergillus tamarii for industrial applications. Revista Mexicana de Ingeniería Química. 2020; 19(1):293-304.

13. Azar RIL, Morales DLM, Alfenas MGP, Falkoski DL, Alfenas RF, Guimarães VM. Apple juice clarification by a purified polygalacturonase from Calonectria pteridis. Food and Bioproducts Processing. 2020;119:238-245.

14. Wasserman B. Thermostable enzyme production. Food Technol. 1984;38:78-88.

15. Silva J, de Franc PRL, Converti A, Porto TS. Kinetic and thermodynamic characterization of a novel Aspergillusaculeatus URM4953 polygalacturonase. Comparison of free and calcium alginate-immobilized enzyme, Process Biochem; 2019.

16. Tan PF, Ng SK, Tan TB, Chong GH, Tan CP. Shelf life determination of durian (Durio zibethinus) paste and pulp upon high-pressure processing. Food Research. 2019;3:221-230.

17. Souza PM, Aliakbarian B, Ximenes E, Filho F, Oliveira P, Pessoa A, Converti A. Kinetic and thermodynamic studies of a novel acid protease from Aspergillus foetidus, Int. J. Biol. Macromol. 2015;81: 17-21.

18. Mozhaev VV. Mechanism-based strategies for protein thermostabilization. Trends Biotechnol. 1993;11:88-95.

19. Illanes A. Stability of biocatalysts. Electron $\mathrm{J}$ of Biocatal. 1999;2(1):1-2.
20. Kanga KA, Koffi DM, Sea TB, Gbotognon OJ, Kouamé PL. Biochemical Characterization of Two Polygalacturonases Purified from the Digestive Juice of the Snail Limicolaria flammea. Biotechnology Journal International. 2021;25(1):41-54

21. Miller $\mathrm{G}$. Use of dinitrosalicylic acid reagent for determination reducing sugar, Anal. Chem. 1959;31:426-428.

22. Lowry $\mathrm{OH}$, Rosebrough $\mathrm{NJ}$, Farra L, Randall RJ. Protein measurement with Folin phenol reagent. J Biol Chem. 1951;193:265-75.

23. Guiavarc'h YP, Deli V, Van Loey AM, Hendrickx ME. Development of an enzymic time temperature integrator for sterilization processes based on Bacillus licheniformis a-amylase at reduced water content. J Food Sci. 2002;67(1):285-91.

24. Stumbo CR. Thermobacteriology in food processing. 2nd edition, Academic Press, New York, NY. 1973;336.

25. Espachs-Barroso A, Van Loey A, Hendrickx M, Martín-Belloso O. Inactivation of plant pectin methylesterase by thermal or high intensity pulsed electric field treatments. Innov Food Sci Emerg Technol. 2006;7(1):40-8.

26. Siddiqui KS, Azhar MJ, Rashid MH, Rajoka MI. Stability and identification of active-site residues of carboxymethylcellulases from Aspergillus niger and Cellulomonas biazotea. Folia Microbiol. 1997;42(4):3128.

27. Riaz MR, Perveen MR, Javed $\mathrm{H}$, Nadeem, $\mathrm{MH}$ Rashi. Kinetics and thermodynamic properties of noval glucoamylase from Humicola sp. Enzyme Microb Technol. 2007;41:558-64.

28. Dogan N, Tari C. Characterization of threephase partitioned exopolygalacturonase from Aspergillus sojae with unique properties. Biochem Eng. J. 2008;39:4350.

29. Faiza A, Haq NB, Muhammad B, Muhammad A. Improvement of activity, thermo-stability and fruit juice clarification characteristics of fungal exopolygalacturonase, International Journal of Biological Macromolecules. 2016;10.086

30. Marangoni AG. Characterization of enzyme stability. In: Enzyme kinetics: a modern approach, John Wiley \& Sons, Inc., Hoboken, NJ; 2003.

31. Ortega N, Diego S, Perez-Mateos $M$, Busto MD. Kinetic properties and thermal 
behavior of polygalacturonase used in fruit juice clarification. Food Chem. 2004; 88:209-217.

32. Muhammad R, Raheela P, Muhammad RJ, Habibullah N, Muhammad HR. Kinetic and Thermodynamic Properties of Glucoamylase from Humicola sp. Enzyme Microb. Technol. 2007;41:558-564.

33. Barrett NE, Grandison AS, Lewis MJ. Contribution of the lactoperoxidase system to the keeping quality of pasteurized milk. Journal of Dairy Research. 1999;66(1):7380.

34. Leite RSR, Gomes E, da Silva R. Characterization and comparison of thermostability of purified $\beta$-glucosidases from a mesophilic Aureobasidium pullulans and a thermophilic Thermoascus aurantiacus. Process Biochemistry. 2007;42(7):1101-1106.

35. Saqib AAN, Hassan M, Khan NF, Baig S. Thermostability of crude endoglucanase from Aspergillus fumigatus grown under solid state fermentation (SSF) and submerged fermentation (SmF)," Process Biochemistry. 2010;45(5):641-646.

36. Rodrigo SRL, Eleni G, Roberto DS. Characterization and composition of thermostability of purified beta-glucosidase from mesophilic Aureobasidium pullulans and a thermophilic Thermoascus aurantiacus. Process Biochem. 2007;42: 1101-1106.
37. Ibrahim E, Mahmoud A, Jones KD, Taylor KE, Hosseney EN, Mills PL, Escudero JM. Kinetics and thermodynamics of thermal inactivation for recombinant Escherichia coli cellulases, cel12B, cel8C, and polygalacturonase, peh28; biocatalysts for biofuel precursor production. Manuscript Submitted to JB. 2020;26-52.

38. Bhatti HN, Zia A, Nawaz R, Sheikh MA, Rashid M H, Khalid AM, - Effect of copper ions on thermal stability of glucoamylase from Fusarium sp. International Journal of Agriculture and Biology. 2005;7:585-587.

39. Anema SG, McKenna AB. Reaction kinetics of thermal denaturation of whey proteins in heated reconstituted whole milk. Journal of Agricultural and Food Chemistry. 1996;44(2):422-428.

40. D'Amico S, Marx J.-C, Gerday C, Feller G. Activity-stability relationships in extremophilic enzymes. Journal of Biological Chemistry. 2003;278(10):78917896.

41. Abdel Wahab WA, Karam EA, Hassan ME, Kansoh AL, Esawya MA, Awad GEA. Optimization of pectinase immobilization on grafted alginateagar gel beads by 24 full factorial CCD and thermodynamic profiling for evaluating of operational covalent immobilization. Int. J. Biol. Macromol. 2018;113:159-170.

(c) 2021 Sea et al.; This is an Open Access article distributed under the terms of the Creative Commons Attribution License (http://creativecommons.org/licenses/by/4.0), which permits unrestricted use, distribution, and reproduction in any medium, provided the original work is properly cited. 